\title{
Cancer Gene Suppression Strategies: Issues and Potential
}

\author{
T. Passioura ${ }^{1}$ and G. Symonds ${ }^{1,2 *}$ \\ ${ }^{1}$ School of Medical Sciences, Faculty of Medicine, \\ University of New South Wales, Kensington, Sydney, \\ Australia \\ ${ }^{2}$ Children's Cancer Institute Australia, Kensington, Sydney, \\ Australia
}

\begin{abstract}
Oncogenes are ideal targets for therapies which down-regulate gene expression. However, effective modalities for altering gene expression in vivo have thus far proven to be elusive. Whilst there has been recent success with small molecule inhibitors of oncoprotein function, evolution of resistance to these agents has been observed in the clinical setting, indicating the need for combinations of therapies for cancer treatment. Strategies for in vivo gene downregulation still hold promise for the treatment of cancer. The technologies relevant to such therapeutic strategies are discussed in terms of molecular action, delivery and choice of target gene. Consideration is given to the pre-clinical and clinical efficacy these agents have demonstrated to date.
\end{abstract}

\section{Introduction}

Cancer arises from the cellular accumulation of genetic alterations, leading to uncontrolled clonal proliferation (Hanahan and Weinberg, 2000). These mutations can be broadly classified into two categories. First, activation of a single allele of a gene which promotes cellular proliferation or survival (oncogene) can occur by point mutation, deletion, chromosomal fusion, gene amplification or dysregulated expression. Secondly, homozygous inactivation of genes which inhibit tumourigenesis (tumour suppressor genes) can occur through any of the above mechanisms excluding gene amplification. Furthermore, inactivation of a tumour suppressor gene may occur by a mutation in one allele that generates a dominant negative protein, causing functional inactivation of the other, wild-type, allele (Kern et al., 1992; Shounan et al., 1996; Shounan et al., 1997). It has been demonstrated in a variety of systems that suppression of expression of one oncogene, or reinstatement of the function of one tumour suppressor gene (which, in some instances can be achieved by inhibiting expression of a dominant negative allele) can revert the transformed phenotype to normal and/or cause the death of the malignant cell (Brummelkamp et al., 2002b; Dolnikov et al., 2000; Kashani-Sabat et al., 1992; Martinez et al.,

*For correspondence. Email gsymonds@medau.jnj.com.
2002; Nielsen and Maneval, 1998; Scherr et al., 1998). Consequently, there has been a substantial amount of research aimed at developing gene therapies or small molecule drugs which inhibit the expression of oncogenes or the activity of oncoproteins.

However, nearly three decades have elapsed since the discovery of the first human oncogenes and, despite the concerted efforts of many researchers, effective therapies specifically targeting oncogenes or their protein products have proven to be frustratingly elusive. Whilst there has been some recent success with the small molecule tyrosine kinase inhibitor Imatinib in the treatment of chronic myeloid leukaemia (CML), the relatively rapid resistance to this drug which occurs in vivo limits its efficacy (Druker et al., 2001b; Druker et al., 2001c; Gorre et al., 2001). Furthermore, the frequency of Imatinib resistance is markedly increased in patients with more advanced disease, which is arguably more analogous to other forms of malignancy than the earlier chronic phase which may persist for years without serious adverse effects (Druker et al., 2001a). These results emphasize the need for combinations of cancer therapies acting through different mechanisms to prevent the evolution of resistant disease (analogous to the cocktails of anti-retroviral drugs used in the treatment of HIV, to prevent the emergence of resistant strains of the virus). In this regard, oncogene suppression gene therapies still offer promise, due to their high specificity and the fact that it is possible to use them in combination with other therapies.

\section{Gene Suppression Technologies}

\section{Antisense}

The use of antisense (reviewed in Pirollo et al., 2003) was the first gene suppression strategy to be tested, and antisense approaches comprise the majority of gene therapy clinical trials to date for the treatment of cancer. Antisense therapeutics are generally small oligonucleotides composed of RNA, DNA or other nucleic acid analogues. They are complementary to a specific sequence in the target mRNA, and bind by standard Watson-Crick base pairing. This inhibits expression of the target gene by decreasing the stability of the target mRNA and/or inhibiting translation. Destabilisation of the mRNA can occur through a variety of mechanisms including induction of RNase $\mathrm{H}$ activity and inhibition of 5'-capping and 3'-polyadenylation (Crooke, 1999). Inhibition of translation may occur through direct blocking of the ribosome, inhibition of splicing and interference with required RNA secondary structures (Crooke, 1999). The most important characteristics of antisense oligonucleotides are those relating to in vivo stability, cellular uptake, specificity/affinity for the target mRNA and ability to suppress gene expression. Accordingly, a number of chemical modifications (primarily 
alterations in sugar and backbone structure) to antisense oligonucleotides have been devised, which optimize these parameters and thereby increase the efficacy and decrease the toxicity of the therapeutic construct (Agrawal and Kandimalla, 2001). In addition to the delivery of synthetic antisense molecules, antisense effects may also be produced through gene expression to produce antisense RNA intracellularly (Medina and Joshi, 1999).

Antisense oligonucleotides can be used to target a wide range of oncogenic targets including over-expressed, point mutated and truncated oncogenes (Chang et al., 1991; Marcucci et al., 2003, Rait et al., 1999). Additionally, antisense approaches may be used to target fusion transcripts in which two cellular genes have become fused leading to the generation of an oncogenic fusion protein (Rapozzi et al., 2002). The archetypal example of this is fusion of the $\mathrm{Bcr}$ and $\mathrm{abl}$ genes during formation of the Philadelphia Chromosome [t(9;22)], characteristic of CML, and which is the molecular target of Imatinib (Druker et al., 2001a).

There are in excess of forty clinical trials of antisense therapeutics and more than half of these are for the treatment of cancer (these are discussed in greater detail below). However, more recently developed gene suppression technologies (RNAi and catalytic nucleic acids, see below) generally exhibit greater efficacy than antisense both in vitro and in animal models. It seems likely, assuming that safety issues do not compromise the development of these other technologies, that they will eventually supplant antisense.

\section{Catalytic Nucleic Acids:}

Ribozymes and Deoxyribozymes.

Ribozymes are small single stranded RNA molecules which have the ability to catalyze the site-specific cleavage of RNA phosphodiester bonds. The first known ribozymes were found in the group I intervening sequence of the pre-RNA of Tetrahymena thermophilia (Cech et al., 1981; Kruger et

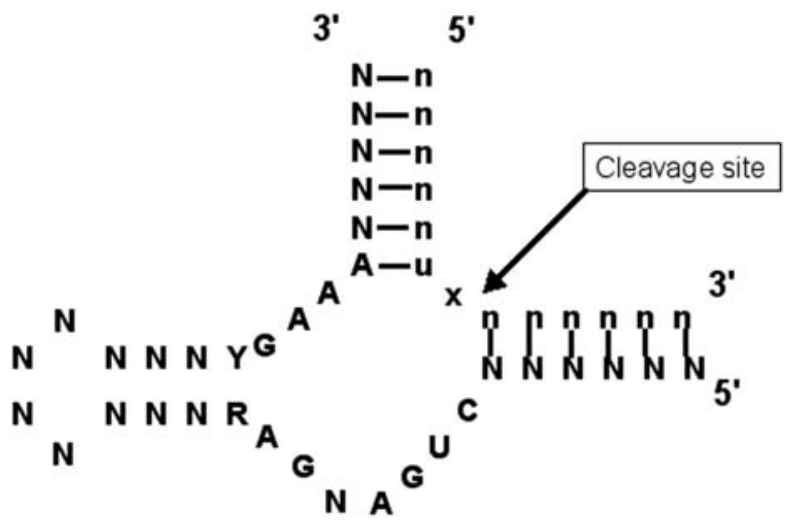

Figure 1. Structure of a trans acting hammerhead ribozyme. Ribozyme sequence is shown in upper case, substrate sequence is shown in lower case with the NUX cleavage triplet upstream of the cleavage site. $N=$ any base, $\mathrm{X}=$ any nucleotide except $\mathrm{G}, \mathrm{R}=$ purine residue, $\mathrm{Y}=$ pyrimidine residue. al. 1982). This sequence catalyses its own excision and, because it cleaves within itself, is termed cis acting. Since that discovery, a number of ribozymes with distinctive structural motifs (hammerhead, hairpin, axehead, etc) have been discovered in a number of organisms (Branch and Robertson, 1991; Buzyan et al., 1986; Forster and Symons, 1987; Guerrier-Takada et al., 1983; Hutchins et al., 1986) and, several of these structural motifs (most notably the hammerhead and hairpin) have been shown able to cleave target sequences in trans (Haseloff and Gerlach, 1988; Uhlenbeck, 1987). The significance of ribozymes which can act in trans is that it is possible to design and construct ribozymes which suppress gene expression through the targeting of specific mRNA transcripts.

The most widely used and studied of the ribozyme structural motifs is the hammerhead ribozyme. The trans acting hammerhead ribozyme (Figure 1) developed by Haseloff and Gerlach in 1988 has minimal substrate requirements and has become the standard model for hammerhead ribozyme design. The only sequence requirement in the substrate is the presence of an NUX sequence where $N$ is any base and $X$ is any base other than $\mathrm{G}$, although, with some variation in efficacy (Zoumadakis and Tabler, 1995). Substrate specificity is determined by standard Watson-Crick base pairing between the two flanking arms of the ribozyme and the RNA substrate. Once the ribozyme has bound the substrate, the phosphodiester bond immediately $3^{\prime}$ of the NUX sequence is cleaved in a reaction involving activation of the 2'-hydroxyl as a nucleophile (Kumar and Ellington, 1995). Breaking of the hydrogen bonds then results in dissociation of the two RNA strands and the ribozyme is free to catalyze another substrate.

The high sequence specificity of ribozymes has sparked a great deal of interest in their use to target mRNA molecules in trans. Through this strategy, specific inhibition of the expression of genes or even mutated versions of genes has been shown to be possible (reviewed in Bramlage et al., 1998). As a specific example, ribozymes have been designed that will not cleave normal ras transcripts but that will cleave mutated (oncogenic) ras transcripts, which differ from their cellular homologues by a single point mutation (Scherr et al., 1997). Delivery of such an anti-ras ribozyme has been shown to reverse mutant ras associated transformation of both fibroblast (KashaniSabet et al., 1992) and haematopoietic cells (Scherr et al., 1998, Dolnikov et al., 2003).

Ribozymes targeting Bcr-abl have been shown to decrease expression of the fusion gene and inhibit cell proliferation in vitro (Snyder et al., 1993; Warashina et al., 1999). Furthermore, anti-Bcr-abl ribozymes have been demonstrated to prevent tissue invasion by leukemic cells and to prolong survival in a murine model of CML (Tanabe et al., 2000). Ribozymes targeting the PML/RAR $\alpha$ fusion [t(15;17)] characteristic of acute promyelocytic leukemia (Nason-Burchenal et al., 1998) and the AML1/MTG8 fusion [t(8;21)] associated with acute myeloid leukemia (Matsushita et al., 1995) have also been demonstrated to be effective in tissue culture systems.

As for antisense, ribozymes may be delivered into a target cell in two ways. First, a synthetic RNA oligonucleotide of the ribozyme may be transfected into a cell directly using 
a standard transfection technique (commonly lipofection, although for clinical trials delivery of naked RNA is more common). Secondly, a "gene" coding for the ribozyme may be delivered into the cell, transcription of which then generates the active ribozyme (Dolnikov et al., 1996). With respect to oncogene suppression therapies, the former of these delivery techniques is complicated by the short half-life of these molecules in vivo caused by the inherent instability of single-stranded RNA molecules in biological systems; indeed, the instability of RNA and the cost of generating RNA in vitro are both significant disadvantages of the use of exogenously delivered RNA molecules. The latter delivery method may be complicated by the problems associated with viral gene delivery, which are discussed in detail below.

One solution to the problem of synthetic ribozyme instability is the use of DNA enzymes (deoxyribozymes, DNazymes, Reviewed in Cairns et al., 2002 and Kachigian, 2000), which take advantage of the significantly increased stability of single-stranded DNA compared with singlestranded RNA in biological systems (Dass et al., 2002). The most efficient RNA cleavage by a DNA enzyme is thought to be that of the so-called 10-23 DNazyme, which was identified by an in vitro selection process (Santoro and Joyce, 1997), and which has been used to target the expression of several genes associated with human malignancy including myc, PKC and Bcr-abl (Sioud and Leirdal, 2000; Sun et al., 1999; Warashina et al., 1999).

\section{RNA Interference}

In the last two years, the phenomenon of RNA interference (RNAi) has emerged as an efficient and selective technique for gene suppression. RNAi is mediated by small (19-23 nucleotides) double stranded RNA molecules (siRNAs or shRNAs, see below), which silence gene expression in a sequence specific manner (Caplen et al., 2001; Elbashir et al., 2001). An attractive feature of RNAi, both as a research tool and as a potential therapeutic, is the extremely high level of gene suppression that is achievable. In many cases, the expression of the target gene is suppressed to levels that are undetectable by Western blotting (Brummelkamp et al., 2002a; Brummelkamp et al., 2002b).
In mammalian cells, RNAi can be triggered by two distinct forms of dsRNA, short interfering RNAs (siRNAs) (Elbashir et al., 2002) and short hairpin RNAs (shRNAs) (Brummelkamp et al., 2002a; Paddison et al., 2002). Current models suggest that shRNAs are processed into siRNAs by the enzyme dicer in an ATP dependent process. siRNAs are then incorporated into the multi-protein RNA Induced Silencing Complex (RISC) in a second ATP dependent step, and mediate the targeting of specific single stranded RNA sequences for cleavage and subsequent degradation (Figure 2). As with antisense and ribozymes, siRNAs can be delivered directly into a cell or a gene expression construct can be introduced. In general, siRNAs are delivered directly and shRNAs are generated intracellularly by transcription, however, strategies have been devised for the intracellular generation of siRNAs by transcription of a short sequence in both directions (Paddison and Hannon, 2002). Delivery of RNAi triggers using retroviral and adenoviral vectors has been demonstrated (Brummelkamp et al., 2002b, Shen et al., 2003). Several groups have demonstrated that systemic delivery of naked siRNAs in mice can have a significant impact upon the expression of either a co-transfused transgene (Lewis et al., 2002; McCaffrey et al., 2002) or an endogenous gene (Song et al., 2003). The latter has, thus far, only been demonstrated in the liver, which is a highly accessible target tissue.

In contrast to antisense and (in general) ribozymes and DNazymes, even a single base discrepancy between the siRNA and target mRNA transcript is sufficient to significantly abrogate the suppressive effect (Semizarov et al., 2003). This extreme specificity has significant implications for the potential use of RNAi as a therapeutic modality for cancer. First, there is the potential (as detailed for ribozymes above) to use RNAi to selectively inhibit expression of oncogenes containing a single point mutation without affecting expression of the wild-type transcript, which may have an essential cellular function. For example, Brummelkamp and coworkers (Brummelkamp et al., 2002b) recently utilized a retrovirally delivered shRNA specific for a mutant $K$-ras allele to inhibit the tumourigenicity of cells which expressed this oncogene, and they demonstrated that this did not affect expression of the wild-type allele.

As with antisense and ribozymes, RNAi based therapies
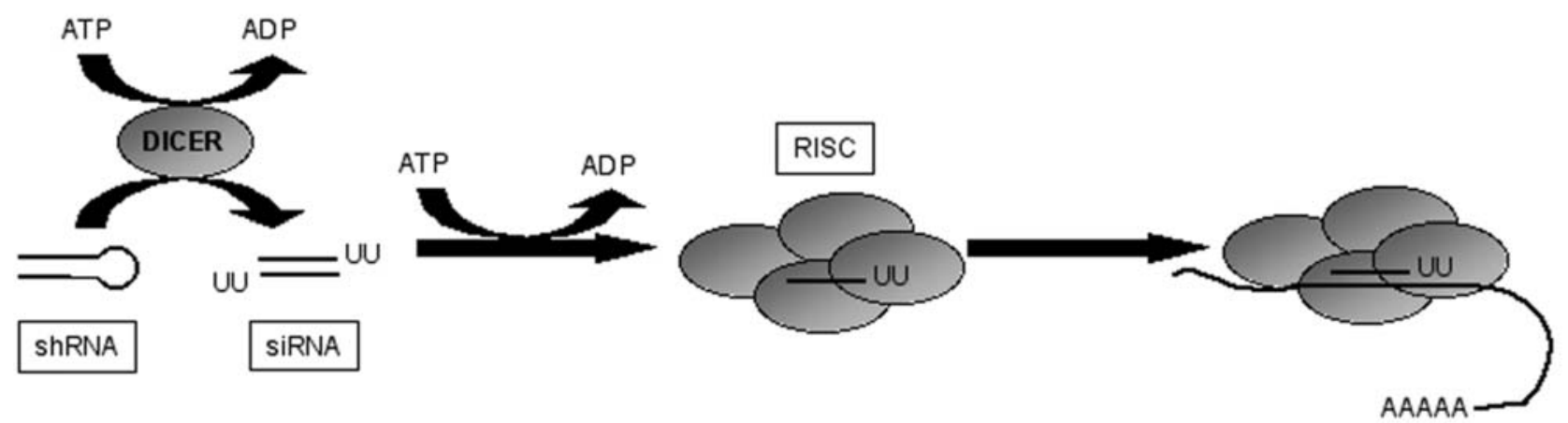

Figure 2. Proposed mechanism of RNAi in mammalian cells. shRNAs are converted into siRNAs by dicer. One strand of the siRNA is incorporated into RISC and mediates targeting and subsequent destruction of the target mRNA. 


\begin{tabular}{|c|c|c|c|}
\hline & Antisense & Ribozyme & RNAi \\
\hline Point-mutant & $\begin{array}{l}\text { Rarely* } \\
\text { (Chang, 1991) }\end{array}$ & $\begin{array}{l}\text { Yes } \\
\text { (Dolnikov, 2003) }\end{array}$ & $\begin{array}{l}\text { Yes } \\
\text { (Brummelkamp, 2002b) }\end{array}$ \\
\hline Fusion gene & $\begin{array}{l}\text { Yes } \\
\text { (Rapozzi, 2002) }\end{array}$ & $\begin{array}{l}\text { Yes } \\
\text { (Tanabe, 2000) }\end{array}$ & $\begin{array}{l}\text { Yes } \\
\text { (Wohlbold, 2003) }\end{array}$ \\
\hline $\begin{array}{l}\text { Dominant negative } \\
\text { tumour suppressor }\end{array}$ & $\mathrm{No}^{\dagger}$ & $\begin{array}{l}\text { Yes } \\
\text { (Watanabe, 2000) }\end{array}$ & $\begin{array}{l}\text { Yes } \\
\text { (Martinez, 2003) }\end{array}$ \\
\hline Truncated gene & $\begin{array}{l}\text { Yes }^{\dagger \dagger} \\
\text { (Rait, 1999) }\end{array}$ & $\begin{array}{l}\text { Yes }^{\dagger \dagger} \\
\text { (Juhl, 1997) }\end{array}$ & $\begin{array}{l}\text { Yes }^{\dagger \dagger} \\
\text { (Nagy, 2003) }\end{array}$ \\
\hline $\begin{array}{l}\text { Over-expressed } \\
\text { Oncogene }\end{array}$ & $\begin{array}{l}\text { Yes }^{\dagger \dagger} \\
\text { (Marcucci, 2003) }\end{array}$ & $\begin{array}{l}\text { Yes }^{\dagger \dagger} \\
\text { (Luzi, 2003) }\end{array}$ & $\begin{array}{l}\text { Yes }^{\dagger \dagger} \\
\text { (Cioca, 2003) }\end{array}$ \\
\hline \multicolumn{4}{|c|}{$\begin{array}{l}\text { "Applicable in a very limited number of specific instances. } \\
\dagger \text { Antisense is not capable of absolute discrimination between the wild-type and mutant transcripts. } \\
\text { t† Will also affect expression of the wild type gene; Only applicable in cases where suppression of the } \\
\text { wild-type gene is non-toxic. }\end{array}$} \\
\hline
\end{tabular}

are potentially amenable to the targeting of oncogenic transcripts in which two cellular genes have become fused leading to the generation of an oncogenic fusion protein. Several groups have shown that siRNAs targeted to the fusion point of the Bcr-ab/ transcript decrease expression of the oncogene and induce apoptosis in Bcr-abl positive cells (Scherr et al, 2002; Wilda et al., 2002; Wohlbold et al., 2003). Furthermore, there is evidence that anti-Bcr-abl siRNAs synergise with Imatinib treatment, even in cells which express Imatinib-resistant Bcr-abl (Wohlbold et al., 2003) suggesting that this may be a useful agent for combination therapy with Imatinib.

\section{Targets and Resistance.}

It can be seen that the use of gene suppression technologies is potentially applicable for the targeting of all oncogenic fusion transcripts (e.g. Bcr-abl, PMLRAR a, AML1/MTG8) and that ribozymes, DNAzymes and RNAi (and, in rare cases, antisense) are applicable for the targeting of oncogenes containing a single, activating point mutation (e.g. ras). However, the targeting of oncogenes which are over expressed as a wild-type transcript (e.g. myc) or genes which are truncated (e.g. EGFR) by these techniques is not so obviously useful, since unselective suppression of such genes in non-tumour tissues may cause toxicity (see Table 1). In such cases, targets need to be assessed on an individual basis, where specificity for the malignant tissue may be conferred not by tumour specific gene suppression but by an "enhanced" tumour specific requirement of the target gene. As an example, overexpressed $b c l-2$ is a valid target for gene suppression therapies because it is required for the survival of malignant tissue, but not required for the survival of most normal tissues (Jansen et al., 2000; Marcucci et al., 2003, Waters et al., 2000).

An important lesson learned from the use of Imatinib is that therapies which combine high specificity with high efficacy exert a strong selective pressure for the emergence of mutations that confer resistance (Gorre et al., 2001; Shah et al., 2002). In view of this, it may be that the extremely high specificity of RNAi will be disadvantageous with respect to the potential use of this technology for the treatment of cancer, since, a single mutation in any of the 19 to 23 base pairs which constitute the siRNA target sequence in the transcript may lead to rapid resistance. Moreover, given the redundancy of the genetic code, virtually any target sequence will contain bases that may be substituted without a corresponding alteration in the cognate translated peptide (silent mutation, Figure 3 ). The implication of this is that resistance to RNAi mediated therapy could be generated with no diminution of function in the oncoprotein, and such therapies are likely to require a combination of RNAi triggers targeted to multiple sites in the target transcript and/or to multiple transcripts. The evolution of resistance to ribozyme based therapies is likely to cause similar problems, although resistance would be expected to occur with lower frequency because it is likely that only mutations in the NUX cleavage site would completely abolish ribozyme activity. Resistance to antisense therapies may be less common than resistance to RNAi, DNAzyme or ribozyme therapies, since several mutations in the target sequence would be required to diminish gene suppression.

\section{Vectors and Delivery}

For gene suppression therapies, as for all gene therapies, a major challenge to be overcome is the development of technologies capable of efficient delivery of nucleic acids into target cells. Pfeiffer and Verma (Pfeiffer and Verma, 2001) have delineated six characteristics of an ideal gene therapy vector: 1) ease of production, 2) safety, 3) sustained and regulatable gene expression, 4) target cell specificity, 5) ability to transduce both dividing and nondividing cells, and 6) site-specific integration. However, for cancer gene therapies, the ability to transduce nondividing cells is likely dispensable, since malignant cells are generally in cycle. Furthermore, if the objective of the 
SiRNA

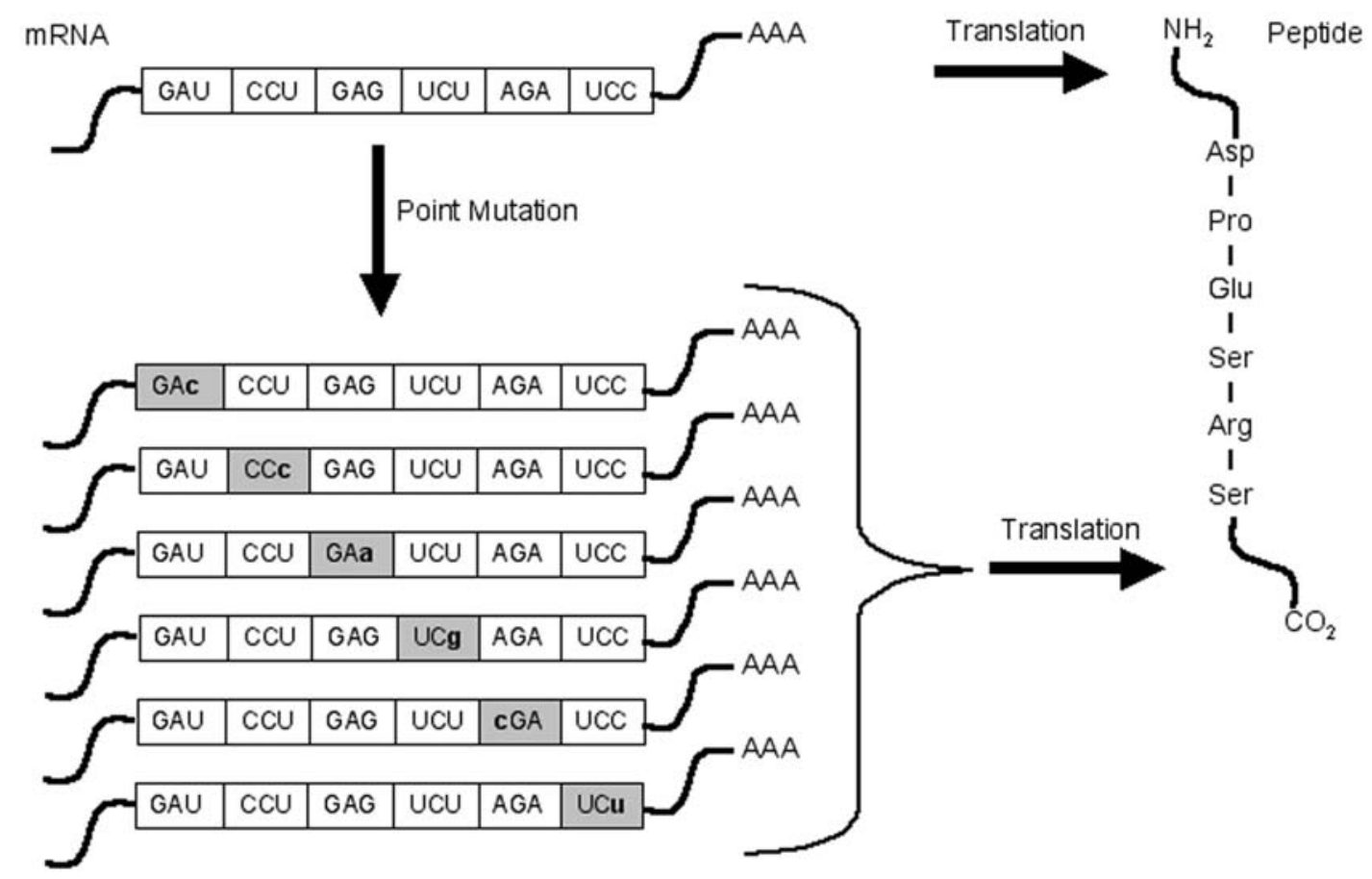

Figure 3. Potential resistance to RNAi based therapies through silent mutation. Because even a single nucleotide discrepancy between the siRNA (top) and target mRNA abrogates gene suppression, there is broad scope for the emergence of point mutations which, due to the redundancy of the genetic code, do not alter the sequence of the translated peptide.

therapy is to destroy the malignant tissue relatively rapidly and not to revert the phenotype to normal, both sustained and regulatable expression, and site-specific integration can also be dismissed. The issue of cell-specificity tends to be dependent upon the "cargo" of the vector. In some gene therapy vectors target-cell specificity is elicited intracellularly (e.g. cell type specific promoters/enhancers, ribozymes or siRNAs targeted to oncogenic alleles) whereas others are restricted through transduction of a specific target cell population. In general, cancer gene suppression strategies rely on the former. Thus, for cancer gene therapies, the single most important characteristic of a vector is the ability to safely transduce cells at high efficiency.

\section{Viral Vectors}

To date, the majority of research on gene therapy vectors has concentrated on modified viruses as a means of nucleic acid delivery. These viral vectors can be broadly classified into two categories, those which integrate into the genome of the target cell (Retroviral including Lentiviral and Adeno-Associated Viral vectors) and those which do not (Adenoviral vectors). In general, viral vectors are internally deleted versions of the wild-type virus, in which only those elements required for infection and delivery of the gene of interest (transgene) into the target cell are retained. Commonly, viral proteins required for production of the viral particle but not for infection are supplied in trans from a packaging construct. Consequently, the viral particles generated are capable of infection of a target cell and delivery of the transgene but are not capable of replication and generally do not exhibit pathogenicity (Pfeiffer and Verma, 2001).

Of the vectors which integrate stably into the genome of the target cell, simple retroviral vectors have received the most attention. Retroviruses are single-stranded RNA viruses (reviewed in Buchschacher, 2001). Upon entry into the target cell, the RNA genome of the virus is reverse transcribed, generating double stranded DNA which integrates into the host genome. Most retroviral vectors are based on the Moloney Murine Leukemia Virus (MoMLV) and these were the first vectors to be used in human gene therapy trials. As noted above, retroviral vectors are internally deleted versions of the wild-type virus, in which the viral replicative genes have been replaced with the gene of interest. (Brummelkamp et al., 2002b; Buchschacher, 2001; Dolnikov et al., 2003)

More recently, vectors derived from more complex retroviruses (lentiviruses) have been developed (reviewed in Quinonez and Sutton, 2002). The principle advantage of these vectors, when compared with earlier retroviral vectors, is that they are capable of infecting quiescent cells. However, because of their increased complexity and the fact that many of these vectors are based on viruses 


\begin{tabular}{|c|c|c|c|}
\hline & Antisense & Ribozyme & RNAi \\
\hline \multicolumn{4}{|c|}{ 1. Anti-apoptosis } \\
\hline bcl-2 & Marcucci, 2003 & Luzi, 2003 & Cioca, 2003 \\
\hline MDR-1 & Astriab-Fisher, 2000 & Scanlon, 1994 & Wu, 2003 \\
\hline \multicolumn{4}{|l|}{ 2. Proliferation } \\
\hline ras & Chang, 1991 & Dolnikov, 2003 & Brummelkamp, 2002b \\
\hline erb & Rait, 1999 & Juhl, 1997 & Nagy, 2003 \\
\hline PKC- $\alpha$ & Lynch, 2003 & Sioud, 1998 & Leirdal, 2002 \\
\hline \multicolumn{4}{|l|}{ 3. Angiogenesis } \\
\hline VEGF & Cheng, 1996 & Sandberg, 2000 & Zhang, 2003 \\
\hline \multicolumn{4}{|l|}{ 4. Metastasis } \\
\hline Mmp9 & Spessotto, 2002 & Hua, 1996 & Sanceau, 2003 \\
\hline \multicolumn{4}{|l|}{ 5. Immortality } \\
\hline Telomerase & Corey, 2002 & Yokoyama, 1998 & Kosciolek, 2003 \\
\hline \multicolumn{4}{|c|}{ 6. Tumour suppressors } \\
\hline mdm2 & Wang, 2001 & Castanotto, 2002 & \\
\hline p53 & & Watanabe, 2000 & Martinez, 2003 \\
\hline
\end{tabular}

with greater pathogenicity (e.g. HIV) than the more simple retroviruses, these vectors are less facile to utilize and will require extensive safety testing before trials in humans.

The predominant non-integrating viral vector systems are those based on adenoviruses (reviewed in Bauerschmitz et al., 2002). Wild-type adenoviruses have double stranded DNA genomes of approximately $36 \mathrm{~kb}$ in length. Adenoviral vectors can accommodate large inserts, and can be produced at high titres (up to $10^{14}$ infectious particles $/ \mathrm{ml}$ ). However, significant toxicities have been shown to be associated with the use of adenoviral vectors including both adaptive and innate immune responses (St George, 2003). To the best of our knowledge, adenoviral vectors have not been used in clinical trials for cancer gene suppression therapies to date, although, they are currently in Phase III clinical trials for replacement of the p53 tumour suppressor gene in the treatment of squamous cell carcinoma (an updated list of ongoing clinical trials can be found at http://www.clinicaltrials.gov).

There are a variety of problems complicating the use of viral vectors in vivo. Overall for all viral vectors these include, but are not limited to: rapid in vivo destuction of virions, immunogenicity of the viral proteins, the potential for insertional mutagenesis with certain vectors and the potential for recombination of the viral vector during production. For these reasons, none of the cancer gene suppression therapies which have progressed to clinical trials so far have employed viral vectors. It should be noted, however, that viral vectors have been used clinically in other cancer gene therapy strategies including the adenoviral delivery of p53 mentioned above and the selectively replicating adenovirus ONYX-015 (Nemunaitis et al., 2003).

\section{Non-Viral Delivery}

Because of the challenges associated with viral delivery of nucleic acids, many gene therapy strategies involve non-viral delivery protocols. These may involve delivery of naked nucleic acid, microencapsulation (Jackson et al., 2002), or the use of a complexing agent. Complexing protocols generally involve the use of cationic polymers, such as positively charged peptides and chitosan (Brown et al., 2001; Guang Liu and De Yao, 2002), or the use of lipoplexes (discussed below). In terms of clinical application, two of these non-viral delivery systems predominate: delivery of naked nucleic acids and delivery of cationic liposome/nucleic acid formulations.

Delivery of naked nucleic acid can be performed via a number of routes, the most used being intratumoural injection and intravenous infusion (Pirollo et al., 2003). Nearly all of the cancer gene suppression clinical trials to date have employed intravenous infusion of a naked construct, with intratumoural injection being second most common. Dose limiting toxicities observed with intravenous infusion of naked nucleic acid tend to be similar regardless of the target and include fatigue, fever, hypotension and thrombocytopenia (Pirollo et al., 2003). Whilst these toxicities are relatively mild, the major limitation of this delivery technique is that it is extremely inefficient, with little clinical evidence of gene suppression (Yuen et al., 2001).

Attempts to increase the efficiency of in vivo transfection using chemical formulations have mainly focussed upon lipoplexes (reviewed in Audouy et al., 2002). These are complexes of nucleic acids with cationic liposomes, which act to facilitate the entry of nucleic acids into cells via endocytosis. This approach has been demonstrated to improve in vivo transfection compared with delivery of naked nucleic acid, however, the liposomal reagents themselves can induce dose limiting toxicities (Dass, 2002). In addition, some cationic liposomes are no less immunogenic than are some viral vectors, and further testing of these formulations is required.

\section{Clinical Application}

For cancer gene suppression therapies, the choice of target gene is crucial to the potential success of the therapeutic approach. This choice is complicated by the 
enormous range of potential targets. Even within a single malignant clone there will be several targetable genes, suppression of which may potentially inhibit neoplasia. The range of targets within a single clone is small, however, when compared to the variety of genes which are mutated in human malignancies. Only a small fraction of these will be present as the mutated gene in a given tumour. One approach to tackling this problem has been to target genes which occur at high frequency in human malignancies (e.g. ras, myc) since these are assumed to be of greater significance to the neoplastic phenotype than those mutations which occur less frequently, and therapies aimed at such genes will be applicable to a greater number of cases. However, frequency is not necessarily a good indication of the suitability of an oncogene for targeting, since frequency is unrelated to the potential phenotypic effect of suppressing such a gene.

One can argue that there is, in fact, only a single primary criterion for selection of a target gene - namely that suppression of the gene (either alone or in combination with another therapy) induces a permanent abrogation of the neoplastic phenotype. However, the inherent genomic instability of malignant cells (Hanahan and Weinberg, 2000) combined with the large number of mutations already present in such cells by the time of clinical presentation, implies that suppression of a single gene may not be capable of inducing a permanent reversal of phenotype. One can then argue that destruction of the malignant clone is the most practicable strategy. With this in mind, there are, hypothetically, six general classes of gene which may be targeted by gene suppression therapies for the treatment of cancer (Table 2), corresponding to the six acquired phenotypic characteristics of malignant cells as defined by Hanahan and Weinberg (Hanahan and Weinberg, 2000). These are: 1) genes which inhibit apoptosis, 2) stimulate proliferation, 3) induce angiogenesis, 4) confer metastatic potential, 5) impart immortality and 6) disrupt tumour suppressive function. The situation is complicated in practice, however, by the fact that many of the genetic mutations associated with malignancy contribute to more than one of these phenotypic characteristics.

\section{Anti-Apoptosis.}

There are two possible mechanisms by which a gene product may prevent apoptosis. Either, the protein may directly inhibit the apoptotic machinery or it may confer resistance to external apoptotic stimuli including chemotherapeutic compounds. Of the former, the $\mathrm{bcl}-2$ gene (which prevents the release of Cytochrome $C$ from the mitochondria, reviewed in Cory and Adams, 2002) has received the most attention as a potential molecular target (Waters et al., 2000). Ribozymes, siRNAs and antisense molecules targeted to $\mathrm{bcl}-2$ have all been shown to induce apoptosis and to increase chemosensitivity in malignant cells of several different origins in a variety of tissue culture systems (Campos et al., Blood 1994; Cioca et al., 2003; Luzi et al., 2003; van de Donk et al., 2003; Ziegler et al., 1997). Furthermore, animal studies using the phosphorothioate modified oligonucleotide Genasense (Oblimersen Sodium, G3139) have demonstrated the efficacy of this $\mathrm{bcl}-2$ antisense molecule both alone and in combination with chemotherapy (Jansen et al., 1998; Klasa et al., 2000; Konopleva et al., 2000; Schlagbauer-Wadl et al., 2000). Phase I and II clinical trials have subsequently shown that this compound is relatively safe (Jansen et al., 2000; Marcucci et al., 2003, Waters et al., 2000), although the clinical impact appeared to be modest. Initial reports from a Phase III clinical trial of Genasense in combination with Dacarbazine for the treatment of advanced malignant Melanoma have been sufficiently promising that a New Drug Application has been initiated with the Food and Drug Administration (Genta press release, September 10, 2003). To date, however, the results from this trial have not been clear, and a longer follow-up is required to prove statistically significant efficacy on an intent-to-treat basis. Additional Phase III clinical trials for Chronic Lymphocytic Leukaemia, Multiple Myeloma and Lung Cancer are currently under way.

The other class of oncogenes that prevent apoptosis are those which confer resistance to external apoptotic stimuli. Amongst these, the MDR1 gene which encodes the drug efflux pump P-glycoprotein has attracted the most attention as a target for clinical intervention. Antisense (Astriab-Fisher et al., 2000), ribozymes (Scanlon et al., 1994) and siRNAs (Wu et al., 2003) have all been used to target MDR1, and all have demonstrated the ability to restore drug sensitivity in tissue culture systems. However, the only anti-MDR1 agents which have progressed to clinical trials are small molecule antagonists.

\section{Proliferation.}

A number of different gene suppression strategies have been devised targeting a range of genes which stimulate the proliferation of malignant cells. Prominent amongst these target genes are members of the erb gene family, including both the epidermal growth factor receptor (EGFR) and the Her2 oncogene (reviewed in Klapper et al., 2000). Antisense (Rait et al., 1999), ribozyme (Juhl et al., 1997) and RNAi (Nagy et al., 2003) strategies targeting erb family members have all been shown to inhibit the proliferation of malignant cells in vitro and an anti-Her2 ribozyme (Herzyme ${ }^{\mathrm{TM}}$ ) is in Phase I clinical trials. In addition, a range of signal transduction molecules including members of the ras, raf and protein kinase families have been targeted using antisense (Chang et al., 1991; Dean et al., 1996; Monia et al., 1996), ribozyme (Sioud and Sorensen, 1998) and RNAi (Brummelkamp et al., 2002b; Leirdal and Sioud, 2002) based strategies. These agents have all shown efficacy in vitro and in xenograft models, however, those antisense molecules which have progressed to clinical trials, whilst relatively well tolerated, have generally not demonstrated high efficacy (Chen et al., 2000; Coudert et al., 2001, Dang et al., 2001). The exception was ISIS 3521, an antisense oligonucleotide targeting the PKC- $\alpha$ gene. In a Phase II clinical trial for the treatment of non-small cell lung cancer (Yuen et al., 2001) this agent, appeared to synergise with chemotherapy (20 of 53 patients demonstrated an objective response), however, a Phase III clinical trial for the same disease showed no significant difference between patients receiving ISIS 3521 and those receiving chemotherapy alone (Lynch et al., 2003). Thus, oncogenes that stimulate proliferation (although, none of those listed 
above are solely linked to proliferation and play important roles in other aspects of malignancy) have not yet been shown to be effective as targets for gene therapies.

\section{Angiogenesis.}

Anti-angiogenic therapies have primarily focused upon the Vascular Endothelial Growth Factor (VEGF) gene, which is a critical mediator of angiogenic signaling (Carmeliet and Jain, 2000). Various strategies have been employed to suppress the expression of VEGF or the VEGF receptor including siRNA, antisense, and ribozymes (Cheng et al., 1996; Zhang et al., 2003). However, despite showing some efficacy in tissue culture and/or animal models, few of these have progressed to clinical trials. The exception is the so-called Angiozyme ${ }^{\mathrm{TM}}$, a ribozyme targeted to the VEGF receptor (Parry et al., 1999). This molecule has demonstrated anti-tumour activity in animal models (Pavco et al., 2000: Sandberg et al., 1999), has been shown to be safe in humans (Sandberg et al., 2000) and a Phase II trial for the treatment of Colorectal Cancer is under way. However, competing technologies such as monoclonal antibodies and small molecule inhibitors may prove to be more effective modalities for blocking angiogenic signaling through this pathway.

\section{Metastasis.}

To the best of our knowledge, there is only a single instance of a gene suppression technology exclusively aimed at the prevention of metastasis. Namely, a ribozyme targeting expression of Matrix Metalloproteinase-9 (Hua and Muschel, 1996). Suppression of this gene using antisense oligonucleotides (Spessotto et al., 2002) and RNAi has also been demonstrated (Sanceau et al., 2003) but assessment of metastatic potential was not the primary focus of these studies.

\section{Immortalty.}

Immortality (the abrogation of proliferative senescence) is a characteristic of all human malignancies. In the majority of tumours immortality is conferred by the telomerase enzyme, which maintains the tandem hexameric repeat caps (telomeres) at the ends of chromosomes and is not expressed in most somatic tissues, making it an ideal target for cancer therapies (reviewed in Shay and Wright, 2002). Telomerase is ribonucleoprotein which has two major components: an integral RNA component (hTERC) and the reverse trascriptase subunit (hTERT), both of which are essential for telomerase function. hTERC has been effectively targeted by number of groups using antisense oligonucleotides (Corey, 2002), ribozymes (Kanazawa et al., 1996; Yokoyama et al., 1998) and siRNA (Kosciolek et al., 2003). However, further pre-clinical testing of these agents is required in order to ensure that toxicities to stem cells (which express telomerase) and lack of efficacy (related to the time lag between inhibition of telomerase and cell death in consequence of erosion of the telomeres) do not present significant clinical obstacles.

\section{Tumour Suppressors.}

The reinstatement of innate tumour suppressive pathways in malignant cells is an extremely attractive therapeutic strategy. Reinstatement of previously inactivated tumour suppressor pathways using gene suppression techniques can be achieved in two ways. First, inhibition of the expression of a dominant negative allele of a tumour suppressor gene can restore wild-type function, since only a single functional allele of a classical tumour suppressor gene is required for induction and maintenance of the wildtype phenotype. For example, to suppress expression of a mutant, dominant negative allele of the p53 tumoursuppressor gene, ribozymes have been designed which repair (Watanabe and Sullenger, 2000) or degrade (Cai et al., 1995) the mutant transcript. Similarly, Martinez and co-workers (Martinez et al., 2002) demonstrated that by targeting a dominant negative allele of this gene with RNAi, it is possible to restore wild-type p53 function in cultured cells. The second mechanism by which reinstatement of tumour suppressor gene function can be effected is based on the observation that in some malignant cells tumour suppressor function is abrogated by the over expression of certain oncogenes. One example of this is over expression of the $m d m 2$ gene, which encodes a p53binding protein that mediates p53 degradation (reviewed in Michael and Oren, 2002). Several groups have shown that a 20 -mer antisense oligonucleotide to $m d m 2$ induces $p 53$ expression and retards growth of cancer cells in vitro (Meye et al., 2000; Tortora et al., 2000). Furthermore, xenograft models have demonstrated that $m d m 2$ antisense therapy synergises with chemotherapeutic agents, and is effective independent of the $p 53$ status (wild-type or mutant) of the target cell (Wang et al., 2001).

\section{Summary}

Although significant advances have been made in the search for specific inhibitors of oncogene expression, significant obstacles remain. The available technologies can be efficacious with respect to down-regulation of the target oncoprotein and can be sufficiently specific. However, delivery of the therapeutic construct to a majority of cancerous cells is still a major impediment to clinical implementation. Despite a large number of clinical pilot studies, we are yet to see a proof-of-principal oncogene suppression therapy, which will demonstrate beyond doubt that this therapeutic strategy has clinical relevence. In this respect, the large number of ongoing clinical trials (mostly antisense oligonucleotide studies) are encouraging, and results of the Phase III trials of the $b c /$-2 antisense molecule Genasense will be particularly interesting. Looking to the future, RNAi and catalytic nucleic acids appear to hold much promise, and the higher efficacy of these technologies when compared with antisense strategies may be sufficient to compensate for the relatively poor delivery that has been achieved to date. 


\section{References}

Agrawal, S., and Kandimalla, E.R. 2001. Antisense and/ or immunostimulatory oligonucleotide therapeutics. Curr. Cancer Drug Targets. 1:197-209.

Astriab-Fisher, A., Sergueev, D.S., Fisher, M., Shaw, B.R., and Juliano, R.L. 2000. Antisense inhibition of Pglycoprotein expression using peptide-oligonucleotide conjugates. Biochem. Pharmacol. 60: 83-90.

Audouy, S.A.L., de Leij, L.F.M.H., Hoekstra, D., and Molema, G. 2002. In vivo characteristics of cationic liposomes as delivery vectors for gene therapy. Pharm. Res. 19:1599-1605.

Bauerschmitz, G.J., Barker, S.D., and Hemminki, A. 2002. Adenoviral gene therapy for cancer: from vectors to targeted and replication competent agents. Int. J. Oncol. 21:1161-1174.

Bramlage, B., Luzi, E., and Eckstein, F. 1998. Designing ribozymes for the inhibition of gene expresion. Trends in Biotech. 16: 434-438.

Branch, A.D., and Robertson, J.D. 1991. Efficient trans cleavage and a common structural motif for the ribozymes of the human hepatitis $\delta$ agent. Proc. Natl. Acad. Sci. USA. 88: 10163-10167.

Brown, M.D., Schatzlein, A.G., and Uchegbu, I.F. 2001. Gene delivery with synthetic (non viral) carriers. Int. J. Pharm. 229: 1-21.

Brummelkamp, T.R., Bernards, R., and Agami, R. 2002a. A system for stable expression of short interfering RNAs in mammalian cells. Science. 296: 550-553.

Brummelkamp, T.R., Bernards, R., and Agami, R. 2002b. Stable suppression of tumorigenicity by virus-mediated RNA interference. Cancer Cell. 2:243-247.

Buchschacher, G.L. Jr. 2001. Introduction to retroviruses and retroviral vectors. Somat. Cell Mol. Genet. 26:1-11.

Buzayan, J.M., Hampel, A., and Bruening, F. 1986. Nucleotide sequence and newly formed phophodiester bond of spontaneously limaged satellite tobacco ringspot virus RNA. Nucleic Acids Res. 14: 9729-9743.

Cai, D.W., Mukhopadhyay, T., and Roth, J.A. 1995. Suppression of lung cancer cell growth by ribozymemediated modification of p53 pre-mRNA. Cancer Gene Ther. 2:199-205.

Cairns, M.J., Saravolac, E.G., and Sun L.Q. 2002. Catalytic DNA: a novel tool for gene suppression. Curr. Drug Targets. 3:269-279.

Campos, L., Sabido, O., Rouault, J.P., and Guyotat, D. 1994. Effects of BCL-2 antisense oligodeoxynucleotides on in vitro proliferation and survival of normal marrow progenitors and leukemic cells. Blood. 84:595-600.

Caplen, N.J., Parrish, S., Imani, F., Fire, A., and Morgan, R.A. 2001. Specific inhibition of gene expression by small double-stranded RNAs in invertebrate and vertebrate systems. Proc. Natl. Acad. Sci. USA. 98:9742-9747.

Carmeliet, P., and Jain, R.K. 2000. Angiogenesis in cancer and other diseases. Nature. 407: 249-257.

Castanotto, D., Li, J.R., Michienzi, A., Langlois, M.A., Lee, N.S., Puymirat, J., and Rossi, J.J. 2002. Intracellular ribozyme applications. Biochem. Soc. Trans. 30:11401145.

Cech, T.R., Zaug, A. J. and Grobowzski, P.J. 1981. In vitro splicing of the ribosomal RNA precursor of Tetrahymena:
Involvement of a guanosine nucleotide in the excision of the intervening sequence. Cell. 27:487-496.

Chang, E.H., Miller, P.S., Cushman, C., Devadas, K., Pirollo, K.F., Ts'o, P.O. and Yu, Z.P. 1991. Antisense inhibition of ras p21 expression that is sensitive to a point mutation. Biochemistry 30:8283-8286.

Chen, H.X., Marshall, J.L., Ness, E., Martin, R.R., Dvorchik, B., Rizvi, N., Marquis, J., McKinlay, M., Dahut, W. and Hawkins, M.J., 2000. A safety and pharmacokinetic study of a mixed-backbone oligonucleotide (GEM231) targeting the type I protein kinase A by two-hour infusions in patients with refractory solid tumors. Clin. Cancer Res. 6:1259-1266.

Cheng, S.Y., Huang, H.J., Nagane, M., Ji, X.D., Wang, D., Shih, C.C., Arap, W., Huang, C.M., and Cavenee, W.K. 1996. Suppression of glioblastoma angiogenicity and tumorigenicity by inhibition of endogenous expression of vascular endothelial growth factor. Proc. Natl. Acad. Sci. USA 93:8502-8507.

Cioca, D.P., Aoki, Y., and Kiyosawa, K. 2003. RNA interference is a functional pathway with therapeutic potential in human myeloid leukemia cell lines. Cancer Gene Ther. 2003 10:125-133.

Coudert, B., Anthoney, A., Fiedler, W., Droz, J.P., Dieras, V., Borner, M., Smyth, J.F., Morant, R., de Vries, M.J., Roelvink, M., European Organization for Research and Treatment of Cancer (EORTC) and Fumoleau, P. 2001. Phase II trial with ISIS 5132 in patients with small-cell (SCLC) and non-small cell (NSCLC) lung cancer. A European Organization for Research and Treatment of Cancer (EORTC) Early Clinical Studies Group Report. Eur. J. Cancer 37:2194-2198.

Corey, D.R. 2002. Telomerase inhibition, oligonucleotides, and clinical trials. Oncogene. 21:631-637.

Cory, S., and Adams, J.M. 2002. The Bcl2 family: regulators of the cellular life-or-death switch. Nat. Rev. Cancer. 2: 647-656.

Crooke, S.T., 1999. Molecular mechanisms of action of antisense drugs. Biochim. Biophys. Acta. 1489:31-44.

Dang, T., Johnson, D., Kelly, K., Rizvi, N., Holmlund, J. and Dorr, A. 2001. Multicenter phase II trial of an antisense inhibitor of H-ras (ISIS-2503) in advanced non-small cell lung cancer (NSCLC). Proc. Am. Soc. Clin. Oncol. 20: 332a.

Dass, C.R. 2002. Cytotoxicity issues pertinent to lipoplexmediated gene therapy in-vivo. J. Pharm. Pharmacol. 54:593-601.

Dass, C.R., Saravolac E.G., Li, Y., and Sun L.Q. 2002. Cellular uptake, distribution, and stability of 10-23 deoxyribozymes. Antisense Nucleic Acid Drug Dev. 12: 289-299.

Dean, N., McKay, R., Miraglia, L., Howard, R., Cooper, S., Giddings, J., Nicklin, P., Meister, L., Ziel, R., Geiger, T., Muller, M. and Fabbro, D. 1996. Inhibition of growth of human tumor cell lines in nude mice by an antisense of oligonucleotide inhibitor of protein kinase $\mathrm{C}$ - expression. Cancer Res. 56:3499-3507.

Dolnikov, A., King, A., Luxford, C., Symonds, G., and Sun, L.Q. 1996. Ribozyme-mediated suppression of v-myc expression abrogates apoptosis in transformed monocytes. Cancer Gene Ther. 3:289-295.

Dolnikov, A., Millington, M., Sun, L-Q., and Symonds, G. 
2000. Induced p21WAF1 expression acts to reverse myc myelomonocytic cell transformation. Cancer Gene Ther. 7:1491-1503.

Dolnikov, A., Shen, S., Millington, M., Passioura, T., Pedler, M., Rasko, J.E.J., and Symonds, G. 2003. A sensitive dual fluorescence reporter system enables positive selection of ras suppressors by suppression of ras-induced apoptosis. Cancer Gene Ther. In Press.

Druker, B.J., Sawyers, C.L., Capdeville, R., Ford, J.M., Baccarani, M., and Goldman, J.M. 2001a. Chronic myelogenous leukemia. Hematology (Am. Soc. Hematol. Educ. Program). :87-112.

Druker, B.J., Sawyers, C.L., Kantarjian, H., Resta, D.J., Reese, S.F., Ford, J.M., Capdeville, R., and Talpaz, M. $2001 b$. Activity of a specific inhibitor of the bcr-abl tyrosine kinase in the blast crisis of chronic myeloid leukemia and acute lymphoblastic leukemia with the philadelphia chromosome. N. Engl. J. Med. 344:1038-1042.

Druker, B.J., Talpaz, M., Resta D.J., Peng, B., Buchdinger, E., Ford, J.M., Lydon, N.B., Kantarjian, H., Capdeville, R., Ohno-Jones, S., and Sawyers, C.L. 2001c. Efficacy and safetey of a specific inhibitor of the bcr-abl tyrosine kinase in chronic myeloid leukemia. N. Engl. J. Med. 344: 1031-1037

Elbashir, S.M., Harborth, J., Lendeckel, W., Yalcin, A., Weber, K., and Tuschl, T. 2001. Duplexes of 21-nucleotide RNAs mediate RNA interference in cultured mammalian cells. Nature. 411:494-498.

Elbashir, S.M., Harborth, J., Weber, K., and Tuschl, T. 2002. Analysis of gene function in somatic mammalian cells using small interfering RNAs. Methods. 26:199-213.

Forster, A.C., and Symons, R.H. 1987. Self-cleavage of plus and minus RNAs of a virusoid and structural model for the active sites. Cell. 49:211-220.

Gorre, M.E., Mohammad, M., Ellwood, K., Hsu, N., Paquette, R., Rao, P.N., and Sawyers, C.L. 2001. Clinical resistance to STI-571 cancer therapy caused by bcr-abl gene mutation or amplification. Science. 293:876-880.

Guang Liu, W., and De Yao, K. 2002. Chitosan and its derivatives--a promising non-viral vector for gene transfection. J. Control Release. 83: 1-11.

Guerrier-Takada, C., Gardiner, K., Marsh, T., Pace, N., and Altman, S. 1983. The RNA moiety of ribonuclease $P$ is the catalytic subunit of the enzyme. Cell. 35:849-857.

Hanahan, D., and Weinberg, R.A. 2000. The hallmarks of cancer. Cell. 100:57-70.

Haseloff, J., and Gerlach, W.L. 1988. Simple RNA enzymes with new and highly specific endoribonuclease activities. Nature. 334:585-591.

Hua, J., and Muschel, R.J. 1996. Inhibition of matrix metalloproteinase 9 expression by a ribozyme blocks metastasis in a rat sarcoma model system. Cancer Res. 56:5279-5284.

Hutchins, C.J., Rathjen, P.D., Forster, A.C., and Symons, R.H. 1986. Self-cleavage of plus and minus RNA transcripts of avocado sunblotch viroid. Nucleic Acids Res. 14:3627-3640.

Jackson, J.K., Liang, L.S., Hunter, W.L., Reynolds, M., Sandberg, J.A., Springate, C., and Burt, H.M. 2002. The encapsulation of ribozymes in biodegradable polymeric matrices. Int. J. Pharm. 243: 43-55.

Jansen, B., Schlagbauer-Wadl, H., Brown, B.D., Bryan,
R.N., van Elsas, A., Muller, M., Wolff, K., Eichler, H.G., and Pehamberger, H. 1998. bcl-2 antisense therapy chemosensitizes human melanoma in SCID mice. Nat. Med. 4:232-234.

Jansen, B., Wacheck, V., Heere-Ress, E., SchlagbauerWadl, H., Hoeller, C., Lucas, T., Hoermann, M., Hollenstein, U., Wolff, K., and Pehamberger, H. 2000. Chemosensitisation of malignant melanoma by BCL2 antisense therapy. Lancet. 356:1728-1733.

Juhl, H., Downing, S.G., Wellstein, A., and Czubayko, F. 1997. HER-2/neu is rate-limiting for ovarian cancer growth. Conditional depletion of HER-2/neu by ribozyme targeting. J. Biol. Chem. 272:29482-29486.

Kachigian, L.M. 2000. Catalytic DNAs as potential therapeutic agents and sequence-specific molecular tools to dissect biological function. J. Clin. Investigation. 106:1189-1195.

Kanazawa, Y., Ohkawa, K., Ueda, K., Mita, E., Takehara, T., Sasaki, Y., Kasahara, A., and Hayashi, N. 1996. Hammerhead ribozyme-mediated inhibition of telomerase activity in extracts of human hepatocellular carcinoma cells. Biochem. Biophys. Res. Commun. 225:570-576.

Kashani-Sabat, M., Funato, T., Tone, T., Jiao, L., Wang, W., Yoshida, E., Kashfinn, B.I., Shitara, T., Wu, A.M., Moreno, J.G., Traweek, S.T., Ahlering, T.E., and Scanlon K.J. 1992. Reversal of the malignant phenotype by an anti-ras ribozyme. Antisense Res. Dev. 2:3-15.

Kern, S.E., Pietenpol, J.A., Thiagalingam, S., Seymour, A., Kinzler, K.W., and Vogelstein, B. 1992. Oncogenic forms of p53 inhibit p53-regulated gene expression. Science. 256:827-830.

Klapper, L.N., Kirschbaum, M.H., Sela, M. and Yarden, Y. 2000. Biochemical and clinical implications of the ErbB/ HER signaling network of growth factor receptors. Adv. Cancer Res. 77:25-79.

Klasa, R.J., Bally, M.B., Ng, R., Goldie, J.H., Gascoyne, R.D., and Wong, F.M. 2000. Eradication of human non-Hodgkin's lymphoma in SCID mice by BCL-2 antisense oligonucleotides combined with low-dose cyclophosphamide. Clin. Cancer Res. 6:2492-2500.

Konopleva, M., Tari, A.M., Estrov, Z., Harris, D., Xie, Z., Zhao, S., Lopez-Berestein, G., and Andreeff, M. 2000. Liposomal Bcl-2 antisense oligonucleotides enhance proliferation, sensitize acute myeloid leukemia to cytosinearabinoside, and induce apoptosis independent of other antiapoptotic proteins. Blood. 95:3929-3938.

Kosciolek, B.A., Kalantidis, K., Tabler, M., and Rowley, P.T. 2003. Inhibition of telomerase activity in human cancer cells by RNA interference. Mol. Cancer Ther. 2: 209-216.

Kruger, K., Grabowski, P.J., Zaug, A.J., Sands, J., Gottschling, D.E., and Cech, T.R. 1982. Self-splicing RNA: Autoexcision and autocyclization of the ribosomal RNA intervening sequence of Tetrahymena. Cell.31:147-157. Kumar, P.K.R., and Ellington, A.D. 1995. Artificial evolution and natural ribozymes. FASEB J. 9:1183-1195.

Leirdal, M., and Sioud, M. 2002. Gene silencing in mammalian cells by preformed small RNA duplexes. Biochem. Biophys. Res. Commun. 295:744-748.

Lewis, D.L., Hagstrom, J.E., Loomis, A.G., Wolff, J.A., and Herweijer, H. 2002. Efficient delivery of siRNA for inhibition of gene expression in postnatal mice. Nat. 
Genet. 2002 32:107-108.

Lewis, D.L., Hagstrom, J.E., Loomis, A.G., Wolff, J.A., and Werweijer, H. 2002. Efficient delivery of siRNA for inhibition of gene expression in postnatal mice. Nat. Genet. 32:107-108.

Luzi, E., Papucci, L., Schiavone, N., Donnini, M., Lapucci, A., Tempestini, A., Witort, E., Nicolin, A., and Capaccioli, S. 2003. Downregulation of bcl-2 expression in lymphoma cells by bcl-2 ARE-targeted modified, synthetic ribozyme. Cancer Gene Ther. 10:201-208.

Lynch, T.J., Raju, R., Lind, M., Riviere, A., Gatzemeier, U., Drorr, A., Holmlund, J., Yuen, A., and Sikic, B. 2003. Randomized phase III trial of chemotherapy and antisense oligonucleotide LY900003 (ISIS 3521) in patients with advanced NSCLC: Initial report. Proc. Am. Soc. Clin. Oncol. 22:623.

Marcucci, G., Byrd, J.C., Dai, G., Klisovic, M.I., Kourlas, P.J., Young, D.C., Cataland, S.R., Fisher, D.B., Lucas, D., Chan, K.K., Porcu, P., Lin, Z-P., Farag, S.F., Frankel, S.R., Zweibel, J.A., Kraut, E.H., Balcerzak, S.P., Bloomfield, C.D., Grever, M.R., and Caligiuri, M.A. 2003. Phase 1 and pharmacodynamic studies of G3139, a bcl-2 antisense oligonucleotide, in combination with chemotherapy in refractory or relapsed acute leukemia. Blood. 101:425432.

Martinez, L.A., Naguibneva, I., Lehrmann, H., Vervisch, A., Tchenio, T., Lozano, G., and Harel-Bellan, A. 2002. Synthetic small inhibiting RNAs: efficient tools to inactivate oncogenic mutations and restore p53 pathways. Proc. Natl. Acad. Sci. USA. 99:14849-14854.

Matsushita, H., Kobayashi, H., Mori, S., Kizaki, M., and Ikeda, Y. 1995. Ribozymes cleave the AML1/MTG8 fusion transcript and inhibit proliferation of leukemic cells with $\mathrm{t}(8 ; 21)$. Biochem Biophys Res Commun. 215:431-437.

McCaffrey, A.P., Meuse, L., Pham, T.T., Conklin, D.S., Hannon, G.J., and Kay, M.A. 2002. RNA interference in adult mice. Nature. 418:38-39.

Medina, M.F., and Joshi, S. 1999. RNA-polymerase IIIdriven expression cassettes in human gene therapy. Curr. Opin. Mol. Ther. 1:580-594.

Meye, A., Wurl, P., Bache, M., Bartel, F., Grunbaum, U., Mansa-ard, J., Schmidt, H., and Taubert, H. 2000. Colony formation of soft tissue sarcoma cells is inhibited by lipidmediated antisense oligodeoxynucleotides targeting the human mdm2 oncogene. Cancer Lett. 149:181-188.

Michael, D., and Oren, M. 2002. The p53 and Mdm2 families in cancer. Curr. Opin. Genet. Dev. 12:53-59.

Monia, B.P., Johnston, J.F., Geiger, T., Muller, M. and Fabbro, D. 1996. Antitumor activity of a phosphorothioate antisense oligodeoxynucleotide targeted against C-raf kinase. Nat. Med. 2:668-675.

Nagy, P., Arndt-Jovin, D.J., and Jovin, T.M. 2003. Small interfering RNAs suppress the expression of endogenous and GFP-fused epidermal growth factor receptor (erbB1) and induce apoptosis in erbB1-overexpressing cells. Exp. Cell Res. 285:39-49.

Nason-Burchenal, K., Allopenna, J., Begue, A., Stehelin, D., Dmitrovsky, E., and Martin, P. 1998. Targeting of PML/ RARalpha is lethal to retinoic acid-resistant promyelocytic leukemia cells. Blood. 92:1758-1767.

Nemunaitis, J., Cunningham, C., Tong, A.W., Post, L., Netto, G., Paulson, A.S., Rich, D., Blackburn, A.,
Sands, B., Gibson, B., Randlev, B., and Freeman, S. 2003. Pilot trial of intravenous infusion of a replicationselective adenovirus (ONYX-015) in combination with chemotherapy or IL-2 treatment in refractory cancer patients. Cancer Gene Ther. 10:341-352.

Nielsen L.L., and Maneval, D.C. 1998. p53 tumour suppressor gene therapy for cancer. Cancer Gene Ther. 5:52-63.

Paddison, P.J., Caudy, A.A., Bernstein, E., Hannon, G.J., and Conklin D.S. 2002. Short hairpin RNAs (shRNAs) induce sequence-specific silencing in mammalian cells. Genes Dev. 16:948-958.

Paddison, P.J., and Hannon, G.J. 2002. RNA interference: the new somatic cell genetics?. Cancer Cell. 2:17-23.

Parry, T.J., Cushman, C., Gallegos, A.M., Agrawal, A.B., Richardson, M., Andrews, L.E., Maloney, L., Mokler, V.R., Wincott, F.E., and Pavco, P.A. 1999. Bioactivity of antiangiogenic ribozymes targeting Flt-1 and KDR mRNA. Nucleic Acids Res. 27:2569-2577.

Pavco, P.A., Bouhana, K.S., Gallegos, A.M., Agrawal, A., Blanchard, K.S., Grimm, S.L., Jensen, K.L., Andrews, L.E., Wincott, F.E., Pitot, P.A., Tressler, R.J., Cushman, C., Reynolds, M.A., and Parry, T.J. 2000. Antitumor and antimetastatic activity of ribozymes targeting the messenger RNA of vascular endothelial growth factor receptors. Clin. Cancer Res. 6:2094-2103.

Pfeifer, A., and Verma, I.M. 2001. Gene therapy: promises and problems. Annu. Rev. Genomics Hum. Genet. 2:177211.

Pirollo, K.F., Rait, A., Sleer, L.S., and Chang, E.H. 2003. Antisense therapeutics: from theory to clinical practice. Pharmacol. Ther. 99:55-77.

Quinonez, R., and Sutton R.E. 2002. Lentiviral vectors for gene delivery into cells. DNA Cell Biol. 21:937-951.

Rait, A., Krygier, J.E., Pirollo, K.F. and Chang, E.H. 1999. Sensitization of breast cancer cells to taxol by antisense HER-2 oligonucleotides. Antisense Nucleic Acid Drug Dev. 9:403-408.

Rapozzi, V., Burm, B.E., Cogoi, S., van der Marel, G.A., van Boom, J.H., Quadrifoglio, F., and Xodo, L.E. 2002. Antiproliferative effect in chronic myeloid leukaemia cells by antisense peptide nucleic acids. Nucleic Acids Res. 30:3712-3721.

St George, J.A. 2003. Gene therapy progress and prospects: adenoviral vectors. Gene Ther. 10:11351141.

Sanceau, J., Truchet, S., and Bauvois, B. 2003. Matrix metalloproteinase- 9 silencing by RNA interference triggers the migratory-adhesive switch in ewing sarcoma cells. J. Biol. Chem. In Press.

Sandberg, J.A., Bouhana, K.S., Gallegos, A.M., Agrawal, A.B., Grimm, S.L., Wincott, F.E., Reynolds, M.A., Pavco, P.A., and Parry T.J. 1999. Pharmocokinetics of an antiangiogenic ribozyme (ANGIOZYME) in the mouse. Antisense Nucleic Acid Drug Dev. 9:271-277.

Sandberg, J.A., Parker, V.P., Blanchard, K.S., Sweedler, D., Powell, J.A., Kachensky, A., Bellon, L., Usman, N., Rossing, T., Borden, E., and Blatt, L.M. 2000. Pharmacokinetics and tolerability of an antiangiogenic ribozyme (ANGIOZYME) in healthy volunteers. J. Clin. Pharmacol. 40:1462-1469.

Santoro, S.W., and Joyce, G.F. 1997. A general purpose 
RNA-cleaving DNA enzyme. Proc. Natl. Acad. Sci. U S A. $94: 4262-4266$.

Scanlon, K.J., Ishida, H., and Kashani-Sabet, M. 1994. Ribozyme-mediated reversal of the multidrug-resistant phenotype. Proc. Natl. Acad. Sci. USA. 91:11123-7.

Scherr, M., Grez, M., Ganser, A., and Engels, J.W. 1997. Specific hammerhead ribozyme-mediated cleavage of mutant N-ras mRNA in vitro and ex vivo. J. Biol. Chem. 272:14304-14313.

Scherr, M., Maurer, A.B., Klein, S., Ganser, A., Engels, J.W., and Grez, M. 1998. Effective reversal of a transformed phenotype by retrovirus-mediated transfer of a ribozyme directed against mutant N-ras. Gene Therapy. 5:12271234.

Scherr, M., Battmer, K., Winkler, T., Heidenreich, O., Ganser, A., and Eder, M. 2002. Specific inhibition of bcrabl gene expression by small interfering RNA. Blood. 101:1566-1569.

Schlagbauer-Wadl, H., Klosner, G., Heere-Ress, E., Waltering, S., Moll, I., Wolff, K., Pehamberger, H., and Jansen, B. 2000. Bcl-2 antisense oligonucleotides (G3139) inhibit Merkel cell carcinoma growth in SCID mice. J. Invest. Dermatol. 114: 725-730.

Semizarov, D., Frost, L., Sarthy, A., Kroeger, P., Halbert, D.N., and Fesik, S.W. 2003. Specificity of short interfering RNA determined through gene expression signatures. Proc. Natl. Acad. Sci. USA. 100:6347-6352.

Shah, N.P., Nicoll, J.M., Nagar, B., Gorre, M.E., Paquette, R.L., Kuriyan, J., and Sawyers, C.L. 2002. Multiple BCR$\mathrm{ABL}$ kinase domain mutations confer polyclonal resistance to the tyrosine kinase inhibitor imatinib (STI571) in chronic phase and blast crisis chronic myeloid leukemia. Cancer Cell. 2:117-125.

Shay, J.W., and Wright, W.E. 2002. Telomerase: a target for cancer therapeutics. Cancer Cell. 2:257-265.

Shen, C., Buck, A., Liu, X., Winkler, M., and Reske, S.N. 2003. Gene silencing by adenovirus-delivered siRNA. FEBS lett. 539:111-114.

Shounan, Y., MacKenzie, K., Dolnikov, A., Miller, M., and Symonds, G. 1997. Myeloproliferative disease and myelodysplastic syndrome induced by transplantation of bone marrow cells expressing mutant p53. Leukemia. 11:1641-1649.

Shounan, Y., Dolnikov, A., MacKenzie, K.L., Chan, YY., and Symonds, G. 1996. Retroviral transduction of hematopoietic progenitor cells with mutant p53 promotes survival and proliferation, modifies differentiation potential and inhibits apoptosis. Leukemia. 10:1619-1628.

Sioud, M., and Leirdal, M., 2000. Design of nuclease resistant protein kinase C-alpha DNA enzymes with potential tharapeutic application. J. Mol. Biol. 296:937947.

Sioud, M., and Sorensen, D.R. 1998. A nuclease-resistant protein kinase $\mathrm{C}$ alpha ribozyme blocks glioma cell growth. Nat. Biotechnol. 16:556-561.

Snyder, D.S., Wu, Y., Wang, J.L., Rossi, J.J., Swiderski, P., Kaplan, B.E., and Forman, S.J. 1993. Ribozyme-mediated inhibition of bcr-abl gene expression in a Philadelphia chromosome-positive cell line. Blood. 82:600-605.

Song, E., Lee, S.-K., Wang, J., Ince, N., Ouyang, N., Min, J., Chen, J., Shankar, P., and Lieberman, J. 2003. RNA interference targeting Fas protects mice form fulminant hepatitis. Nat. Med. 9:347-351.

Spessotto, P., Rossi, F.M., Degan, M., Di Francia, R., Perris, R., Colombatti, A., and Gattei, V. 2002. Hyaluronan-CD44 interaction hampers migration of osteoclast-like cells by down-regulating MMP-9. J. Cell Biol. 158:1133-1144.

Sun, L.Q., Cairns, M.J., Gerlach, W.L., Witherington, C., Wang, L., and King, A. 1999. Suppression of smooth muscle cell proliferation by a c-myc RNA-cleaving deoxyribozyme. J. Biol. Chem. 274:17236-17241.

Tanabe, T., Kuwabara, T., Warashina, M., Tani, K., Taira, K., and Asano, S. 2000. Oncogene inactivation in a mouse model. Nature. 406:473-474.

Tortora, G., Caputo, R., Damiano, V., Bianco, R., Chen, J., Agrawal, S., Bianco, A.R., and Ciardiello, F. 2000. A novel MDM2 anti-sense oligonucleotide has anti-tumor activity and potentiates cytotoxic drugs acting by different mechanisms in human colon cancer. Int. J. Cancer. 88: 804-809.

Uhlenbeck, O.C. 1987. A small catalytic oligoribonucleotide. Nature. 328:596-600.

van de Donk, N.W.C.J., Kamphuis, M.M.J., van Dijk, M., Borst, H.P.E., Bloem, A.C., and Lokhurst, H.M. 2003. Chemosensitization of myeloma plasma cells by an antisense-mediated downregulation of bcl-2 protein. Leukemia. 17:211-219.

Wang, H., Nan, L., Yu, D., Agrawal, S., and Zhang, R. 2001. Antisense anti-MDM2 oligonucleotides as a novel therapeutic approach to human breast cancer: in vitro and in vivo activities and mechanisms. Clin. Cancer Res. 7:3613-3624.

Warashina, M., Kuwabara, T., Nakamatsu, T., and Taira, K. 1999. Extremely high and specific activity of DNA enzymes in cells with a philadelphia chromosome. Chem. Biol. 6:237-250.

Watanabe, T., and Sullenger, B.A. 2000 Induction of wildtype p53 activity in human cancer cells by ribozymes that repair mutant p53 transcripts. Proc. Natl. Acad. Sci. USA. 97:8490-8494.

Waters, J.S., Webb, A., Cunningham, D., Clarke, P.A., Raynaud, F., di Stefano, F., and Cotter, F.E. 2000. Phase I Clinical and pharmacokinetic study of bcl-2 antisense oligonucleotide therapy in patients with non-hodgkin's lymphoma. J. Clin. Oncol. 18:1812-1823.

Wilda, M., Fuchs, U., Wössmann, W., and Borkhardt, A. 2002. Killing of leukemic cells with a BCR/ABL fusion gene by RNA interference (RNAi). Oncogene. 21:5716-5724.

Wohlbold L., van der Kuip, H., Miething, C., Vornlocher, H-P., Knabbe, C., Duyster, J., and Aulitzky, W.E. 2003. Inhibition of bcr-abl gene expression by small interfering RNA sensitizes for imatinib mesylate (STI571). Blood. In Press.

Wu, H., Hait, W.N., and Yang, J-M. 2003. Small interfering RNA-induced suppression of MDR1 (P-glycoprotein) restores sensitivity to multidrug-resistant cancer cells. Cancer Res. 63:1515-1519.

Yokoyama, Y., Takahashi, Y., Shinohara, A., Lian, Z., Wan, X., Niwa, K., and Tamaya, T. 1998. Attenuation of telomerase activity by a hammerhead ribozyme targeting the template region of telomerase RNA in endometrial carcinoma cells. Cancer Res. 58:5406-5410.

Yuen, A., Halsey, J., Fisher, G., Advani, R., Moore, M., Saleh, M., Ritch, P., Harker, G., Ahmed, F., Jones, C., 
Polikoff, J., Keiser, W., Kwoh, T., Holmlund, J., Dorr, A. and Sikic, B., 2001. Phase I/II trial of ISIS 3521, an antisense inhibitor of PKC-alpha, with carboplatin and paclitaxel in non-small cell lung cancer. Proc. Am. Soc. Clin. Oncol. 20:309a.

Zhang, L., Yang, N., Mohamed-Hadley, A., Rubin, S.C., and Coukos, G. 2003. Vector-based RNAi, a novel tool for isoform-specific knock-down of VEGF and antiangiogenesis gene therapy of cancer. Biochem. Biophys. Res. Commun. 303:1169-1178.
Ziegler, A., Luedke, G.H., Fabbro, D., Altmann, K.H., Stahel, R.A., and Zangemeister-Wittke, U. 1997. Induction of apoptosis in small-cell lung cancer cells by an antisense oligodeoxynucleotide targeting the Bcl-2 coding sequence. J. Natl. Cancer Inst. 89:1027-1036.

Zoumadakis, M., and Tabler, M. 1995. Comparative analysis of cleavage rates after systematic permutation of the NUX consensus target motif for hammerhead ribozymes. Nucleic Acids Res. 23:1192-96. 


\section{Further Reading}

Caister Academic Press is a leading academic publisher of advanced texts in microbiology, molecular biology and medical research. Full details of all our publications at caister.com

- MALDI-TOF Mass Spectrometry in Microbiology Edited by: M Kostrzewa, S Schubert (2016) www.caister.com/malditof

- Aspergillus and Penicillium in the Post-genomic Era Edited by: RP Vries, IB Gelber, MR Andersen (2016) www.caister.com/aspergillus2

- The Bacteriocins: Current Knowledge and Future Prospects Edited by: RL Dorit, SM Roy, MA Riley (2016)

www.caister.com/bacteriocins

- Omics in Plant Disease Resistance Edited by: V Bhadauria (2016) www.caister.com/opd

- Acidophiles: Life in Extremely Acidic Environments Edited by: R Quatrini, DB Johnson (2016) www.caister.com/acidophiles

- Climate Change and Microbial Ecology: Current Research and Future Trend

Edited by: J Marxsen (2016)

www.caister.com/climate

- Biofilms in Bioremediation: Current Research and Emerging Technologies

Edited by: G Lear (2016)

www.caister.com/biorem

- Microalgae: Current Research and Applications Edited by: MN Tsaloglou (2016) www.caister.com/microalgae

- Gas Plasma Sterilization in Microbiology: Theory, Applications, Pitfalls and New Perspectives Edited by: H Shintani, A Sakudo (2016) www.caister.com/gasplasma

- Virus Evolution: Current Research and Future Directions Edited by: SC Weaver, M Denison, M Roossinck, et al. (2016) www.caister.com/virusevol

- Arboviruses: Molecular Biology, Evolution and Control Edited by: N Vasilakis, DJ Gubler (2016) www.caister.com/arbo

- Shigella: Molecular and Cellular Biology Edited by: WD Picking, WL Picking (2016) www.caister.com/shigella

-Aquatic Biofilms: Ecology, Water Quality and Wastewater Treatment

Edited by: AM Romaní, H Guasch, MD Balaguer (2016)

www.caister.com/aquaticbiofilms

- Alphaviruses: Current Biology

Edited by: S Mahalingam, L Herrero, B Herring (2016)

www.caister.com/alpha

- Thermophilic Microorganisms

Edited by: F Li (2015)

www.caister.com/thermophile
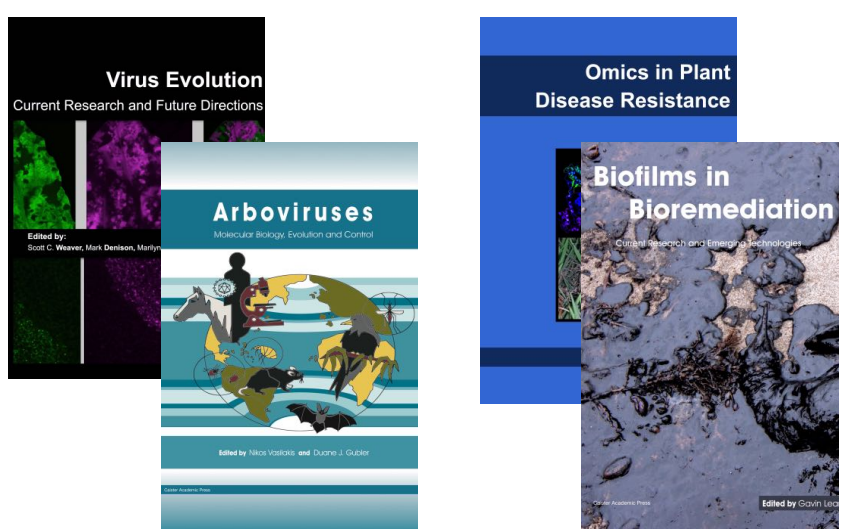
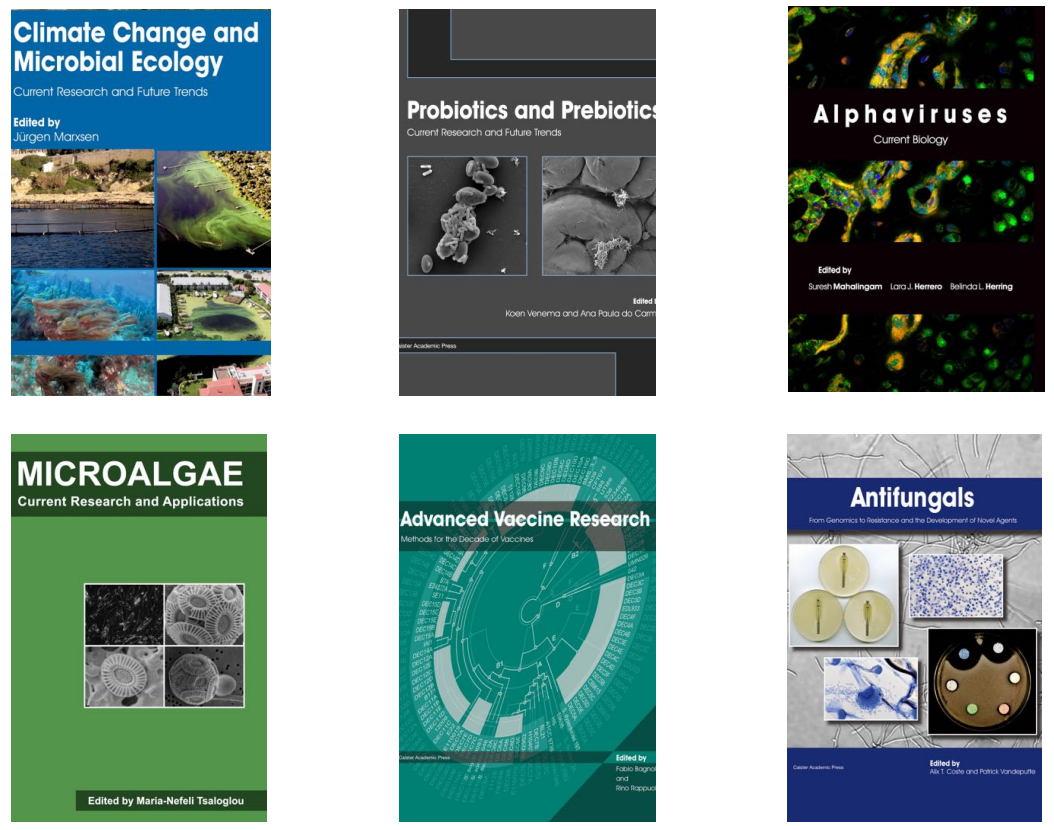

- Flow Cytometry in Microbiology: Technology and Applications Edited by: MG Wilkinson (2015) www.caister.com/flow

- Probiotics and Prebiotics: Current Research and Future Trends Edited by: K Venema, AP Carmo (2015) www.caister.com/probiotics

- Epigenetics: Current Research and Emerging Trends Edited by: BP Chadwick (2015) www.caister.com/epigenetics2015

- Corynebacterium glutamicum: From Systems Biology to Biotechnological Applications

Edited by: A Burkovski (2015)

www.caister.com/cory2

- Advanced Vaccine Research Methods for the Decade of Vaccines

Edited by: F Bagnoli, R Rappuoli (2015)

www.caister.com/vaccines

- Antifungals: From Genomics to Resistance and the Development of Novel Agents

Edited by: AT Coste, P Vandeputte (2015)

www.caister.com/antifungals

- Bacteria-Plant Interactions: Advanced Research and Future Trends Edited by: J Murillo, BA Vinatzer, RW Jackson, et al. (2015) www.caister.com/bacteria-plant

\section{- Aeromonas}

Edited by: J Graf (2015)

www.caister.com/aeromonas

- Antibiotics: Current Innovations and Future Trends

Edited by: S Sánchez, AL Demain (2015)

www.caister.com/antibiotics

- Leishmania: Current Biology and Contro Edited by: S Adak, R Datta (2015) www.caister.com/leish2

- Acanthamoeba: Biology and Pathogenesis (2nd edition) Author: NA Khan (2015)

www.caister.com/acanthamoeba2

- Microarrays: Current Technology, Innovations and Applications Edited by: Z He (2014)

www.caister.com/microarrays2

- Metagenomics of the Microbial Nitrogen Cycle: Theory, Methods and Applications

Edited by: D Marco (2014)

www.caister.com/n2 